\title{
特〔集 「循環器系薬剤のトレンドこ」
}

\author{
はじめに \\ 瀬在 \\ 明 \\ 日本大学医学部外科学系心臟血管 ·呼吸器 · 総合外科学分野
}

本号では, 『循環器系薬剤のトレンド2』として, 降 圧薬について, 各専門の先生方に最新の話題を執筆して いただきました。現在，降圧治療として，RAS 阻害薬 が中心に使用されています。以前は欧米での大規模研究 の結果からその有効性が示され，使用していたのが日本 の現状ですが，近年，日本独自の大規模研究も行われる ようになり，その有効性が報告されつつあります。その なかで, 同系統の降圧薬の class effect 部分はもちろ ん, drug effect な部分の報告も散見されるようになり， 患者の状態，合併症の有無などにより，今まで以上によ り厳密に各種薬剤を選択すべき時代に突入しています。

日本に拈ける新たな高血圧治療ガイドライン (JSH2014) が 5 年ぶりに改訂され，本年 4 月に発表さ れますが, 昨年, その改訂概要の報告がありました。 JSH2009 では若年・中年の降圧目標值は＜130/85 mmHg でありましたが, <140/90 mmHg に変更されました。 高齢者は前期と後期に分けられ，隠れた合併症の多い 高齢者ではまず＜150/90 mmHg を目指し，忍容性があ れば<140/90 mmHg を目指すことが推奨されています. 糖尿病合併患者について, 2013 年に発表された「ESH/ ESC 高血圧管理ガイドライン」では, 糖尿病患者に対 する厳格な降圧を支持するエビデンスがないとして降圧 目標值が<130/80 mmHg から<140/85 mmHg に引き上 げられました。しかし，日本人に多い脳卒中は厳格な 降圧の有効性が認められていることから，JSH2014で は引き続き糖尿病患者の降圧目標值は $<130 / 80 \mathrm{mmHg}$ となっています。筋梗塞後の目標值はJSH2009 では
<130/80 mmHg に設定されていましたが，心筋虚血が あると血圧值と心血管イベント発生率に J カーブ現象が 認められるとの報告があるため, JSH2014 では心疾患合 併症患者の降圧目標值を $<140 / 90 \mathrm{mmHg}$ に統一し, 可 能であれば＜130/80 mmHg を目指すこととなりました。 また CKD 合併患者については, JSH2009 での降圧目標 值は＜130/80 mmHg でしたが, JSH2014では蛋白尿陰 性の場合，<140/90 mmHgに引き上げられました。蛋 白尿陽性の場合は $<130 / 80 \mathrm{mmHg}$ に据え置かれました。 またJSH2014では，合併症のない高血圧患者に対する 第一選択薬は利尿薬, Ca 拮抗薬, ACE 阻害薬, ARB の 4 種が推奨されることになりました。ただし，狭心 症, 心筋梗塞後, 心不全などの心疾患合併患者に対して は積極的な $\beta$ 遮断薬の適応となっています.

血圧測定について, JSH2014では, 診察室血圧と家庭 血圧で診断が異なる場合, 診察室血圧ではなく家庭血圧 を採用した際の診断が優先されています.

高齢化の進む日本において，高血圧患者は増加してお り, 今後は各患者に合わせた適切な血圧管理が必要と考 えられます。そのなかで, 同系統の降圧薬の class effect な部分はもちろん, drug effect な部分の特徴を理解され, 患者の状態, 合併症の有無などにより, 今まで以上によ り厳密に各種薬剤を選択すべき時代に突入していると考 えております。

今回の特集が先生方の日々の臨床にお役立ていただ き, 患者さんにより良い医療を届けられる一助となれば と思っております。 